\title{
Increased Fibroblast Growth Factor Pathway Activation
}

National Cancer Institute

\section{Source}

National Cancer Institute. Increased Fibroblast Growth Factor Pathway Activation. NCI

Thesaurus. Code C161613.

A finding indicating increases in fibroblast growth factor (FGF) activity, activation of FGFdependent pathways and proliferation of cells in a cellular sample. 